\title{
NASI WONG WONGAN PERSPEKTIF RELIGIUS MAGIS
}

\author{
Sang Ayu Made Yuliari \\ Program Studi Kesehatan Ayurweda Fakultas Kesehatan \\ Universitas Hindu Indonesia Denpasar \\ Email :yuliari@unhi.ac.id
}

\begin{abstract}
Abstrak
Artikel yang berjudul "Nasi Wong-Wongan Perspektif Religius Magis", ini membahas tentang nasi yang berwujud manusia atau dibuat dalam bentuk /wujud manusia sebagai salah satu persembahan diantara banyak persembahan yang ada. Nasi wong-wongan ini dalam upacara yang lebih besar sebagai salah satu pelengkap dalam banten caru. Adanya fenomena wabah yang melanda negeri ini khususnya di Bali bagi umat Hindu sangat meyakini dengan persembahan ini akan dapat menghindari wabah yang terjadi. Segala upaya dtelah dilakukan termasuk himbauan kepada prejuru untuk melakukan persembahyangan di seluruh desa adat di Bali. Hal ini dilakukan agar masyarakat di Bali tetap tenang dan berserah diri kepada Tuhan. Berdasarkan keyakinan umat Hindu di Bali sebuah banten bersifat magis karena di dalamnya ada mantera yang diuncarkan oleh seorang sulinggih yang memimpin suatu upacara. Banten yang dalam hal ini berupa nasi wong-wongan bersifat niskala dan sekala serta memiliki daya magis. Dengan banten tersebut dapat memberikan vibrasi yang positif sehingga terhindar dari hal-hal yang tidak diinginkan.
\end{abstract}

\section{Kata Kunci: Wong-wongan, Perspektif, Religius magis}

\begin{abstract}
The article, entitled "Wong-Wongan Rice, Magical Religious Perspective", discusses rice that is human in form or made in human form / form as one of the offerings among many offerings. Wong-wongan rice is in a larger ceremony as one of the complement in banten caru. The existence of the plague phenomenon that hit this country, especially in Bali for Hindus strongly believes that this offering will be able to avoid the plague that occurred. All efforts have been made including appeals to preachers to pray in all traditional villages in Bali. This is done so that people in Bali remain calm and surrender to God. Based on the beliefs of Hindus in Bali a banten is magical because in it there is a spell that is cast by a sulinggih who presides over a ceremony. Banten, in this case in the form of rice wong-wongan is noetic and scale and has magical power. With these offerings can provide a positive vibration so as to avoid things that are not desirable.
\end{abstract}

Keyword : Wong-Wongan, Perspective, magical Religious 


\section{Pendahuluan}

Belakangan ini nasi wong wongan menjadi perbincangan yang sangat serius, di tengah covid 19. Terjadinya covid 19 ini membuat masyarakat dan dunia ketakutan. Karena begitu banyak kematian akibat covid 19 atau virus corona ini. Para dokter, para medis, petugas kesehatan berjuang di depan melawan virus corona tersebut. Di dalam perjuangan itu ada dokter dalam menjalankan tugasnya meningggal dunia karenanya. Covid 19 begitu mengguncang dunia dari bulan Pebruari sampai april 2020 ini belum juga reda. Dengan adanya virus ini masyarakat banyak kehilangan pekerjaan, terutama pekerjaan harian, kalau tidak bekerja maka mereka tidak dapat makan. Himbaun pemerintah kepada

masyarakat, untuk tetap tinggal di rumah, membuat masyarakat menjadi dilema.Apabila tidak mematuhi anjuran pemerintah maka akan dikenakan sangsi demikian juga bila tinggal di rumah, bagi pekerja harian tidak menghasilkan uang untuk dapat menopang hidupnya. Inilah virus corona atau disebut covid 19 yang membunuh manusia tidak kenal ampun. Virus corona tidak pilih kasih dalam menyerang manusia baik itu kaya, miskin, pejabat, anakanak, remaja, dewasa, pekerja harian, artis dan semua golongan dapat diserangnya. Demikian hebatnya virus corona ini tidak hanya membunuh yang sudah terjangkit, akan tetapi dapat juga membunuh orang yang sehat karena tidak dapat bekerja mencari sesuap nasi untuk menghidupi diri dan keluarganya.

Di tengah merebaknya virus corona masyarakat kebingungan harus berbuat apa dan masyarakat menjadi sangat kawatir dengan adanya social media yang memberitakan pemberitaan yang tidak benar atau hoak. Di tengah pandemi covid 19 ini ada juga orang yang tidak bertanggungjawab menyebarkan berita yang tidak benar dari mana sumbernya, sehingga masyarakat menjadi tambah resah. Akibat adanya pandemic ini banyak masyarakat atau orang kehilangan pekerjaannya. Begitu juga para pengusaha seperti hotel, restoran, pasar seni sementara tutup sampai batas waktu yang tidak ditentukan. Selain itu dunia pendidikan juga kena dampaknya seperti belajar dari rumah, tidak boleh berkumpul dengan banyak orang. Walaupun ada social media yang dapat membantu untuk belajar, pengeluaran biaya juga sangat dirasakan dengan keadaan ini. Bagaimana tidak, dengan diam di rumah tidak bekerja, tidak menghasilkan sementara kebutuhan sehari -hari harus terpenuhi, belum lagi membeli paket untuk dapat mengerjakan tugas yang diberikan oleh guru.Virus corona yang begitu dahsyatnya berpengaruh terhadap perekonomian di semua bidang. Ribuan orang kehilangan pendapatannya karena tempat mereka kerja tutup. Terlebih di Bali hidup berdasarkan pariwisata yaitu pariwisata budaya yang diilhami oleh agama Hindu. Banyak hotel dibangun di Bali dan mempekerjakan ribuan karyawan yang sekarang menjadi sepi pengunjung. Semuanya berdampak terutama masyarakat bawah paling merasakan akibat virus corona ini. Ekonomi menjadi lesu, banyak orang yang hidunya berada di bawah garis kemiskinan tambah merana dan tidak berdaya. Di tengah pandemic ini banyak hal yang terjadi dan yang sangat menyedihkan adalah orangorang yang 
dengan sengaja menimbun masker, hansanitezer demi untuk keuntungan sendiri, sementara paramedic berjuang melawan corona virus. Untuk mendapatkan APD (alat pelindung diri ) saja sangat susah oleh karena itu kita sendiri harus mempunyai kesadaran untuk membantu diri sendiri dan orang lain.

Berbagai fenomena yang terjadi di masyarakat akibat pandemic covid 19 ini, yang membuat perekonomian di Indonesia secara umum mengalami penurunan. Kapan wabah ini berakhir, belun diketahui dengan pasti. Dengan ketidak menentuan ini, masyarakat kelas bawah mulai merasakan akibatnya. Semua masyarakat berdoa agar penanganan covid 19 ini dapat ditangani dengan cepat oleh pemerintah dan masyarakat juga harus bersinergi untuk dapat mengendalikan covid tersebut.Negara-negara yang maju seperti Amerika yang merupakan Negara adidaya juga tidak berdaya melawan covid 19 ini. Hal ini mungkin teguran dari Tuhan untuk kita semua bahwa ada kekuasaan yang lebih kuasa daripada kekuasaan manusia. Manusia yang mempunyai kekuasaan biasanya tumbuh menjadi orang-orang yang egois. Tuhan mungkin berkali-kali telah memperingatkan kepada manusia agar selalu menjaga alam semesta sehingga hidup menjadi harmonis. Peringatan itu mungkin tidak dapat diterjemahkan oleh manusia, sehingga manusia semakin serakah mengeruk kekayaan alam untuk kepentingan dirinya. Manusia dapat membuat beraneka ragam senjata, teknologi semakin canggih tetapi tetap tidak dapat mengalahkan kekuasaan Tuhan. Dengan covid 19 ini Tuhan memberikan peringatan yang keras agar manusia kembali kejalannya menjalankan kemanusiaannya. Seluruh dunia menangis akibat virus ini. Dalam keadaan seperti ini tidak ada jalan lain kecuali berserah diri kepada Tuhan. Karena sakit dan penyakit semua diciptakan oleh Tuhan itu sendiri. Dalam keyakinan Hindu di Bali sakit diciptakan oleh dewa Brahma. Dewa Brahma sebagai dewa pencipta, dapat menciptakan sakit dan penyakit sekaligus pengobatannya.

Wabah yang terjadi seperti sekarang ini yang dikenal dengan virus covid 19, sampai seluruh dunia merasakan akibatnya, di Bali pada zaman dahulu dikenal dengan gerubug. Gerubung dan virus covid 19 mungkin ada kemiripan, karena orang yang terserang virus covid 19 ini bisa meninggal dunia bahkan ribuan orang juga sudah meninggal. Demikian juga gerubug yang pernah ada di Bali yaitu sebelum kemerdekaan Republik Indonesia, sering terjadi wabah yang merajalela di desa-desa. Gerubug yang acapkali membawa kematian pada waktu itu adalah muntah missing atau ngutah bayar (muntah berak, kolera). Ratusan manusia meninggal dalam jangka waktu yang amat singkat. Gerubug ini sangat ditakuti oleh masyarakat. Para Dewa dapat mengirim penyakit ke dunia, itu sebagai hukuman kepada manusia akibat kelalaiannya yaitu telah berbuat menyalahi dharma agama. Perbuatan yang dianggap menyalahi dharma agama adalah melakukan sad ripu, tidak pernah sembahyang, tidak menghormati orang tua, suka berbuat tidak baik. (Nala,1993:175). Penyakit datang dari Tuhan, Brahman atau Hyang Widhi melalui dewa Brahma, ajaran untuk membuat penyakit diturunkan kepada para Durga beserta bhuta-bhutinya. Bhuta-bhuti inilah yang dapat menakut-nakuti manusia sehingga manusia dapat pingsan karena ketakutan. Dengan ketakutan itu maka Durga dapat masuk ke dalam tubuh sehingga 
seseorang menjadi sakit. Mungkin bhuta-bhuti ini sejenis virus yang tidak dapat dilihat oleh mata telanjang. Untuk menyembuhkan dan melawan penyakit ini Tuhan juga yang memberikan caranya. Melalui dewa Wisnu mengajarkan usada dan dharma agama kepada Bhagawan Kasyapa untuk membasmi penyakit itu. Jadi dengan demikian penyakit dan obat datang dari Tuhan, Brahma atau Hyang Widhi. Dunia sekarang ini dilanda wabah yang mematikan yaitu virus corona dan para alhi dibidang pengobatan berusah untuk menemukan obat untuk menyembuhkan virus tersebut. Berbagai usaha dilakukan untuk melawan virus itu. Khususnya di Bali untuk melawan virus corona itu berbagai usaha juga dilakukan sesuai dengan keyakinan umat Hindu di Bali. Dengan berserah diri kepada Tuhan, karena semua itu juga berasal dari Tuhan maka wajib diserahkan kembali kepada Tuhan melalui persembahan. Serentak seluruh umat Hindu di Bali menghaturkan sesajen untuk memohon kepada Tuhan agar terhindar dari virus corona tersebut. Banyak jenis sesajen yang dapat dipersembahkan kepada Tuhan seperti segehan manca warna, nasi kepelan, nasi wong-wongan dan daun pandan berduri yang berisi bawang jahe serta benang tridatu. Semua upaya ini dilakukan sematamata untuk menangkal wabah yang sedang terjadi dan untuk membuat perasaan menjadi tenang. Dengan perasaan yang tenang maka pikiran juga menjadi positif. Berdasarkan hal tersebut di atas maka nasi wong-wongan penting diungkap kembali untuk memberikan pemahaman yang lebih dalam kepada masyarakat.

\section{Metode}

Penulisan artikel ini menggunakan metode pustaka yaitu mengkaji berdasarkan pustakapustaka yang berkaitan dengan judul artikel. Pustaka pokok yang digunakan adalah Salinan Lontar Pupulan Indik Caru Lan Tawur. Demikian juga berdasarkan pengamatan di lingkungan sekitar yang menggunakan nasi wong-wongan sebagai suatu persembahan yang dikaitkan dengan adanya wabah seperti sekarang ini yaitu wabah virus covid 19. Hal ini dilakukan sesuai dengan keyakinan dan kepercayaan dari umat Hindu di Bali.

\section{Pembahasan}

\subsection{Mengapa Nasi Wong-Wongan?}

Sebelum membahas lebih dalam tentang nasi wong-wongan, ada baiknya pembahasan dimulai dengan beberapa pengertian terkait dengan nasi wong-wongan.Nasi dalam Kamus Istilah Agama Hindu adalah sebagai sarana upakara agama seperti : nasi angkeb, nasi bira, nasi gibungan, nasi isehan, nasi yasa, nasi kepel, nasi kojong, nasi pangkonan, nasi prajnan, nasi sasah, nasi segan dan nasi wong-wongan (Anonim, 2005 :17). Dalam Kamus Bahasa Bali Wong artinya orang, juga mempunyai arti nama ingkel yang pertama (Anandakusuma,1986:224). Sejalan dengan Anandakusuma wong artinya orang, wayang, wayang orang, nasi wongwongan yaitu nasi yang berbentuk orang, wong juga berarti nama ingkel yang pertama (wong ,sato, mina, manuk, taru, buku ) (Anonim,2005 :862). Jadi nasi wong-wongan yaitu nasi yang dibuat sebagai sarana upakara dalam wujud orang atau bentuk manusia.

Beraneka ragam persembahan yang dapat dipersembahkan kepada Tuhan seperti jenis-jenis 
nasi sebagai sarana upakara. Adapun jenis-jenis nasi tersebut yaitu: nasi kepelan, nasi sasah, nasi angkeb, nasi kojong, nasi bira, nasi prajnan, nasi isehan, nasi sega dan nasi wongwongan.Terjadinya wabah yang melanda negeri ini membuat umat Hindu di Bali melakukan persembahan berupa nasi wong-wongan.Nasi wong-wongan termuat dalam salinan lontar

pupulan Indik Caru Lan Tawur. Dalam salinan lontar tersebut dikatakan sebagai berikut."Malih caruning bilang bucu pekarangan segaa wongwongan amanca warna anut panca warna pada asiki maaled don telujungan matatakan klakat pada misi dupa asiki sowang-sowang”. Dari kutipan tersebut dapat diartikan sebagai berikut: dan lagi upacara mecaru di setiap pojok pekarangan rumah dengan segaa wong-wongan amancawarna sesuai dengan lima warna menurut tempatnya memakai daun atau ujung daun pisang/talujungan dengan wadahnya klakat yang dibuat dari bambu dan diisi dengan dupa setiap segaa wong-wongan satu. Berdasarkan apa yang tersurat dalam pupulan lontar indik caru lan tawur tersebut dalam menghaturkan segaa wong-wongan disesuaikan dengan tempat arah mata angin dan tujuannya seperti menjaga pekarangan rumah sehingga setiap pojok di rumah dipersembahkan segaa. Hal ini juga bila mengadakan upacara yang lebih besar. Seperti segaa barak letakkan di daksina/selatan, segaa ireng/hitam tempatkan di utara, segaa putih tempatkan di timur, di tengah-tengah segaa brumbun. Nasi wong-wongan yang lazim digunakan di masyarakat yaitu berwarna putih sebagai pelengkap upacara caru yang lebih besar. Belakangan terjadi masyarakat atau umat Hindu di Bali terkait dengan virus corona ini membuat dan menghaturkan nasi wong-wongan di depan rumah/diwang/di luar rumah dengan beraneka warna. Ada yang membuat nasi wong-wongan dengan wujud orang diberi warna seperti tangan kanan diberi warna merah, tangan kiri diberi warna kuning, kepala warna putih, kaki warna hitam dan badan warna manca warna. Ada juga orang yang membuat nasi wong-wongan lengkap dengan mata hidung dan lainnya. Hal ini merupakan kearipan local, dimana umatnya kreatif berimajinasi sehingga ada berbagai bentuk nasi wong-wongan. Berdasarkan pupulan indik caru lan tawur, nasi wong-wongan disebutkan amanca warna. Hal ini sesuai dengan panduan Dinas Pemajuan Masyarakat Adat Provinsi Bali (www.com radar jawapos.com, tanggal akses 17 April 2020). Namun, berdasarkan pengamatan di lapangan menurut sarati/tukang banten nasi wong-wongan berwarna putih dan berwujud manusia, tidak berwarna warni karena segehannya sudah amanca warna.

Selain dalam bentuk orang ada lagi nasi dalam berbagai bentuk seperti yang disebutkan dalam salinan lontar Pupulan Indik Caru Lan Tawur yaitu pada caru karang panes disebutkan sebagai berikut."Muah bhuta slurik paha ganjaraning sarwa bhucari sedananya sega mawarna mareka jati, mapinda macan ring gneya, mapinda durgadewi ring neriti, mapinda nagaraja ring wayabya, mapinda garudapati ring airsanya, mapinda wong-wongan ring madya, jangkep sowang-sowang ring pasangannya, pada sowangsowang maaled don talujungan,

matatakan klakat sudhamala...........dan seterusnya”. (Anom Ida Bagus:14). Dari kutipan tersebut dapat diketahui bahwa bentuk nasi tersebut tidak hanya dalam bentuk orang tetapi 
juga ada berbagai bentuk sesuai dengan tujuan tujuan tertentu seperti : nasi bentuk macan, bentuk durgadewi dan bentuk garuda. Dari berbagai bentuk tersebut disesuaikan dengan tempatnya gneya/tenggara nasi dengan bentuk macan, neriti/di barat daya nasi dalam bentuk durgadewi, wayabya/barat laut nasi dalam bentuk nagaraja, airsanya/timur laut nasinya berbentuk garuda dan madya/di tengah nasi berbentuk manusia. Adapun

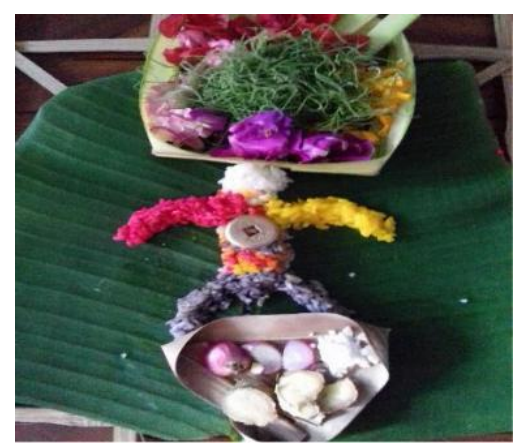

Nasi wong-wongan amanca warna (sumber penelitian )

\subsection{Sarana Nasi wong-wongan}

Adapun sarana nasi wong-wongan itu antara lain

a. Nasi. Nasi dibuat dari beras, kemudian direndam sampai berasnya lembut kurang lebih tiga puluh menit, kemudian dimasak/dikukus selama sepuluh sampai dengan lima belas menit. Setelah lima belas menit beras yang setengah matang tersebut diaru, diamkan selama sepuluh menit sampai airnya meresap ke beras yang diaru. Setelah itu panaskan panci pengukus, masukkan aruannya itu dimasak sampai sepuluh menit, inilah nasi yang sudah matang. Nasi sebagai sarana untuk membuat nasi wong-wongan, ada yang membuat nasi wong- nasi wong-wongan tersebut dilengkapi dengan bawang, jahe, garam, isinya sama dengan segehan biasa yang dilakukan setiap hari kajeng kliwon. Nasi wong-wongan ini sama dengan segehan yang berfungsi sebagai (1) persembahan,

(2) sebagai permohonan dan (3) sebagai penetralisir/somya dari hal-hal yang bersifat negative. Adapun bentuk nasi wong-wongan itu sebagai berikut.

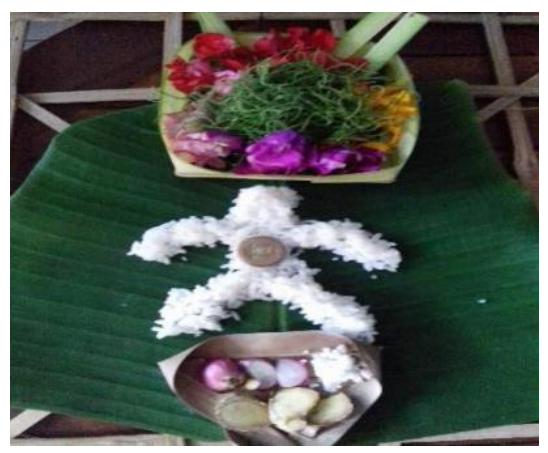

Nasi wong-wongan putih (sumber penelitian)

wongan putih, ada yang amanca warna. Nasi wong-wongan dialasi dengan daun pisang/talujungan/ujung daun pisang. Nasi putih mengandung karbohidrat yang utama menjadi makanan pokok terutama di Indonesia. Dalam satu porsi nasi putih berukuran satu mangkok (180 gram), setidaknya mengandung 50 gram karbohidrat. Selain itu nutrisi yang terkandung dalam nasi putih adalah vitamin B1, B2, B3, B6, protein, zat besi, fosfor, selenium, mangan dan magnesium(www.com_alodokter.com, akses tanggal 19 April 2020). Walaupun demikian nutrisi yang terdapat pada nasi putih, jangan berlebihan makan nasi karena dapat menyebabkan deabetis oleh 
karena itu makanlah secukupnya sesuai dengan kebutuhan tubuh.

b. Bawang Merah (Allium Cepa.B)

Bawang adalah salah satu bumbu dapur yang juga dapat digunakan sebagai sarana dalam membuat sesajen. Bawang juga sering digunakan untuk obat tradisional, misalnya bila sakit panas, punggung diusug dengan menggunakan minyak kelapa dan bawang merah.

Demikian juga bila membuat loloh diisi dengan bawang merah yang ditambus atau dipanggang pada bara api, kemudian baru dicampur dengan loloh tersebut. Bawang merah di dalam Ayurweda disebut dengan Palandu. Umbi bawang merah/palandu mula khasiatnya sama dengan rasona/bawang putih. Umbi palandu/bawang merah ini mempunyai usna guna, tetapi tidak terlalu panas, serta memiliki svadu rasa dan svadu vipaka (manis). Campuran ramuan bawang merah ini sering digunakan sebagai vajikarana yaitu untuk meningkatkan seksual, meningkatkan bala/kekuatan dan sebagai rucya meningkatkan nafsu makan (Nala,2001:181). Secara sekala bawang merah dapat digunakan sebagai sarana obat, secara niskala bawang merah diyakini dapat menolak bala atau kekuatan yang negative. Bawang merah ini biasanya juga digunakan pada saat bayi baru lahir, dibuatkan pelangkiran salah satu isinya adalah bawang merah.Dalam pupuh pucung disebutkan sebagai berikut “ Bibi anu lamun payu luwas manjus, antenge tekekang, yatnain ngaba masui, tiyuk puntul bawang anggen sasikepan”. Dari pupuh tersebut memberikan gambaran bahwa betapa pentingnya bawang merah itu, yang digunakan sebagai sasikepan (semacam senjata) untuk menangkal hal-hal yang kurang baik. Dalam pengobatan tradisional banyak sekali manfaat dari mawang merah.Bawang merah (Allium Cepa.B) ini dapat mengatasi penyakit pusing, vertigo, pengeng. Adapun ramuannya adalah : umbi berambang/bawang, rimpang kencur, kelapa gading. Pengolahannya bahan digiling halus, ditambah air dan peras, pemakaian yaitu ditutuh (tetes hidung) dengan air perasan (Nala,1993:222). dan banyak lagi kegunaan dari bawang merah.

c. Jahe ( Adraka) (Zingiber Officinale R ). Jahe selain sebagai sarana upakara seperti dalam segehan atau nasi wongwongan, jahe juga dapat digunakan sebagai obat. Jahe dalam Ayurweda disebut dengan adraka. Adraka merupakan tanaman yang mempunyai rimpang, yang dapat dipergunakan untuk meurunkan unsur kapha dan vatta. Jahe ini juga digunakan untuk memperbaiki suara. Disamping itu pula dapat digunakan unutk mengobati sembelit, obat sula/sakit kolik. Rimpang jahe ini memiliki rasa pedas dan usna guna/panas, meningkatkan seksual, sebagai tonikum atau penguat jantung. 
Walaupun demikian banyak fungsi jahe, jahe sebaiknya tidak diberikan pada orang yang menderita penyakit kusta, anemia, demam, daha/sensasi terbakar (Nala,2001:182). Jahe juga dapat mengatasi penyakit rematik dengan ramuan sebagai berikut : rimpang jahe, rimpang lengkuas, rimpang bangle, dan rempah-rempah (sindrong jangkep) semua bahan digerus /diulig dipakai boreh (Nala,1993 :234).

d. Garam

Garam juga merupakan salah satu bumbu dapur yang sering digunakan untuk menambah rasa dalam masakan. Garam dalam agama Hindu diyakini dapat menangkal hal-hal yang besifat negative, di Bali disebut dengan uyah areng. Uyah areng ini diperoleh dengan tunggku dapur/bungut jalikan (tempat memasak tradisional). Uyah areng dioleskan di bungut jalikan, sehingga uyah berubah menjadi hitam. Dalam mengoleskan uyah ke tunggu dapur sambil memohon kepada dewa Brahma agar dapat memusnahkan penyakit yang diderita oleh seseorang. Demikian juga untuk menjaga pekarangan rumah/ nyengker, ditaburi dengan uyah areng di sekeliling rumah. Hal ini dilakukan bila ada salah satu anggota keluarga yang sedang sakit.

Garam dibutuhkan oleh setiap manusia untuk keseimbangan cairan dan fungsi saraf maupun otot. Kandungan natrium pada garam dapat berfungsi untuk menjaga keseimbangan cairan, kesehatan jantung dan ginjal. Garam juga berfungsi mengatur aliran darah sehingga mencegah tekanan darah rendah maupun darah tinggi.Lebih lanjut Maxie menyebutkan bahwa garam berfungsi sebagai pelengkap kandungan nutrisi yang dibutuhkan oleh tubuh dan dalam garam mengandung unsur sodium dan klorin. Sosdium dinilai penting untuk mengatur proses keseimbangan cairan tubuh, transmisi darah dan kerja otot.)(www.com cnnindonesia.com,akses tanggal18 April 2020). Demikian banyak manfaat garam sehingga dari zaman dahulu para leluhur menggunakan sebagai salah satu bentuk ramuan obat.

e. Uang kepeng/uang.

Uang dalam bahasa Sanskerta mempunyai arti artha. Pengertian artha sesungguhnya adalah tujuan. Uang membantu melancarkan seseorang untuk mencapai tujuan, karena itu uang disebut artha. Di dalam keyakinan umat Hindu uang kepeng digunakan sebagai sesari dan lambang untuk mengganti segala kekurangan yang tidak disengaja dalam pelaksanaan upacara tersebut (Wiana,2009:31).Uang sebagai sesari yang juga mempunyai arti sarining manah/idep atau pikiran yang suci dipersembahkan kepada Tuhan.

\subsection{Perspektif}

Menurut Joel M Charon pengertian Perspektif adalah kerangka konseptual, perangkat asumsi, 
perangkat nilai dan perangkat gagasan yang mempengaruhi persepsi seseorang sehingga pada akhirnya dapat mempengaruhi tindakan seseorang dalam situasi tertentu. Sedangkan Martono (2010) mengatakan perspektif adalah cara pandang terhadap suatu masalah yang terjadi atau sudut pandang tertentu yang digunakan dalam melihat suatu fenomena. Ardianto dan Q Anees (2007) mendefinisikan perspektif adalah cara pandang atau sudut pandang kita terhadap sesuatu (www.com, tanggal akses, 16 April 2020). Jadi perspektif dalam tulisan ini adalah cara pandang umat Hindu dalam meyakini tentang nasi wong-wongan.

\subsection{Religius Magis}

Religius dalam Kamus Besar Bahasa Indonesia adalah bersifat relegi, bersifat keagamaan yang bersangkut paut dengan relegi. Relegi adalah kepercayaan kepada Tuhan, kepercayaan akan adanya kekuatan adikodrati di atas manusia,

kepercayaan animisme,dinamisme, agama (https://kbbi.web.id/relegi) tanggal akses,16 April 2020).Magis /gaib dalam Kamus Filsafat berasal dari bahasa Inggris yatu magic, bahasa Latin yaitu magicus dari kata magia dan dari Bahasa Yunani mageia. Magis mempunyai beberapa pengertian yaitu : (1) magi adalah salah satu bentuk agama primitive. Dalam magi banyak gejala yang dihubungkan dengan kekuatan gaib, (2) magi juga dapat diartikan sebagai ritus yang mempunyai tujuan mempengaruhi orang, binatang, roh-roh dan lain-lain, (3) Magi primitive dipelajari secara lengkap oleh Levy Bruhl dan N Marr (1864-1934). Menurut mereka magi adalah terkandung suatu pemikiran yang spesifik. Dalam bentuk pemikiran seperti ini belum bisa ditarik suatu pembedaan kualitatif antara benda-benda. Karena itu terjadi pemindahan ciri-ciri dari suatu gejala atau hal ke beberapa gejala dan hal lain. Manusia primitive menganggap pemindahan seperti itu sebagai realitasyang tidak berubah dimana tidak ada tempat bagi hal yang adikodrati (supernatural).Bila "pemikiran magi" ada bersama pemikiran logis, magi sebagai suatu tindakan berkaitan dengan konsepsi kekuatan adikodrati yang muncul kemudian. Konsepsi biasa mengenai magi berkaitan dengan keyakinan akan terpenuhinya secara langsung hasrat-hasrat manusiawi tanpa tindakan-tindakan yang secara logis diorientasikan pada tujuan yang dimaksud. (misalnya pulihnya seseorang dari sakit keras hanya dengan membakar kemenyan dan mengacungacungkan keris dan lain-lain) (Bagus Lorens,2005:557). Dari beberapa pengertian di atas maka religius magis dalam tulisan ini adalah keyakian atau kepercayaan umat Hindu di Bali dalam aktivitas keagamaan dengan sarana nasi

wong-wongan yang diyakini dapat menghindarkan diri dari wabah yang sedang terjadi.Dengan adanya wabah pandemic covid 19 ini banyak umat mempersembahkan sesajen terutama nasi wong-wongan dipersembahkan secara khusus atau lebih spesifik.

Berdasarkan uraian tersebut di atas dapat diketahui bahwa nasi wong-wongan yang dijadikan sebagai salah satu sesajen diantara banyak sajen yang ada. Persembahan berupa nasi wong-wongan karena mempunyai nilai magis.Dimana magis adalah berhubungan dengan hal-hal yang bersifat gaib. Umat Hindu di Bali meyakini adanya dua unsur yang berbeda yaitu sekala dan niskala. Penyakit yang berhubungan dengan sekala dapat disembuhkan oleh perawat, dokter, Balian seperti contoh luka akibat kena 
pisau, akibat jatuh hal ini jelas dapat disembuhkan. Apabila sakit yang disebabkan oleh niskala yaitu yang tidak tampak oleh mata maka umat Hindu disamping berobat ke dokter, ke Balian juga melalui berdoa dengan sarana sajen yaitu nasi wong-wongan. Persembahan berupa nasi wongwongan ini dilakukan biasanya terjadi hal-hal yang ganjil atau dalam satu keluarga mengalami sakit keras yang tidak kunjung sembuh, seperti wabah virus yang terjadi yang tidak tampak oleh mata. Hal ini merupakan suatu keganjilan yang sedang melanda negeri ini. Umat Hindu di Bali berdasarkan keyakinannya maka nasi wong-wongan sebagai pilihan untuk mengurangi kekacauan atau gerubug itu. Menurut kepercayaan umat Hindu gerubug disebabkan oleh bhuta bhuti dan durgadewi untuk mengacau alam semesta ini. Durgadewi/Dewi Durga merupakan manifestasi Tuhan dalam fungsinya untuk memberikan sangsi pada perbuatan yang jahat. Sangsi dari Tuhan itu sebenarnya bukanlah suatu hukuman tetapi sebagai media pendidikan untuk memacu umat manusia agar lebih sadar berbuat yang benar atau di jalan dharma. Hal ini dilakukan Tuhan bukanlah untuk membalas dendam. Tuhan tidak memiliki rasa dendam, Tuhan adalah perwujudan kasih (Wiana,2009 :32). Oleh karena itu nasi wongwongan ini sebagai penyomya para bhuta tersebut agar tidak lagi menyebarkan penyakit.Nasi wongwongan yang dilengkapi dengan sarana bawang, jahe dan garam merupaka perpaduan yang sangat

sempurna untuk menetralisir dan menyeimbangkan unsur sekala dan niskala demikian juga unsur vatta, pitta dan kapha yaitu tiga unsur yang ada dalam tubuh.Apabila salah satu dari unsur tersebut tidak seimbang maka tubuh akan sakit. Tubuh adalah bhuwana alit dan alam semesta adalah bhuwana agung, keduanya ini hendaknya ada dalam keseimbangan. Penggunaan bawang, jahe dan garam apabila dilihat dari cara memperolehnya yaitu jahe dan bawang adalah tanaman yang terdapat di darat dan garam terdapat di laut. Jadi dengan demikian darat dan laut menyatu dalam satu kesatuan yang dapat menciptakan keseimbangan. Berdasarkan persembahan berupa nasi wong-wongan dengan sarana yang lainnya diyakini dapat menyomya bhuta yang negative menjadi positif atau menjadi dewa sehingga tidak lagi mengganggu kehidupan manusia.

\section{Simpulan dan Saran}

\subsection{Simpulan}

Berdasarkan pembahasan di atas maka Nasi wong-wongan sebagai salah satu persembahan sesuai dengan keyakinan umat Hindu di Bali dapat disimpulkan sebagai berikut.

1. Berwujud manusia

2. Untuk menyonya bhuta menjadi dewa

3. Sebagai alat komunikasi secara sekala dan niskala.

4. Secara umum banten sebagai unsur pendidikan untuk meningkatkan kualitas diri.

\subsection{Saran}

Adapun saran yang dapat disampaikan pada kesempatan ini adalah :

1. Kepada masyarakat di dalam melaksanakan yadnya hendaknya berdasarkan sastra-sastra dalam ajaran Agama Hindu 
2. Kepada peneliti selanjutnya terutama di bidang humaniora hendaknya lebih banyak mengungkap tradisi-tradisi di msayarakat untuk dikaji dan ditulis kembali .

3. Sebagai bahan bacaan dan warisan bagi generasi berikutnya.

\section{Daftar Pustaka}

Anandakusuma, Sri Reshi,1986.Kamus Bahasa Bali.Penerbit.CV Kayumas

Anonim,2005. Kamus Bali Indonesia.Penerbit. Balai Bahasa Pusat Bahasa Departemen Pendidikan Nasional.
Anom ,Ida Bagus. Salinan Lontar Pupulan Indik Caru lan Tawur. Geriya Kediri Kuwum Anyar Marga.

Bagus, Lorens,2005. Kamus Filsafat. Penerbit PT. Graamedia Pustaka Utama Jakarta.

Nala,Ngurah,2001.Ayurveda Ilmu Kedokteran Hindu2.Penerbit Upada Sastra Denpasar.Cetakan I.

..............1993.Usada Bali.Penerbit Upada Sastra Denpasar. Cetakan II.

Wiana,2009.Suksmaning Banten.Penerbit Paramita.

https://kbbi.web.id/relegi tanggal akse,16 April $\underline{2020 .}$

www.com,cnnidonesia.com, tanggal akses, 16,17,19 2020. 
